\title{
Suppressive activity of enzymatically-educed soy protein hydrolysates on degranulation in IgE-antigen complex-stimulated RBL-2H3 cells
}

\section{Tolulope Joshua Ashaolu and Chutha Takahashi Yupanqui ${ }^{1}$}

${ }^{1}$ Interdisciplinary Graduate School of Nutraceutical and Functional Food (IGS-NFF), Prince of Songkla University, 90112 Hat Yai, Songkla, Thailand

Corresponding author: Chutha Takahashi Yupanqui, PhD, Interdisciplinary Graduate School of Nutraceutical and Functional Food (IGS-NFF), $9^{\text {th }}$ Floor, LRC Building, Prince of Songkla University, 90112 Hat Yai, Songkla, Thailand

Submission Date: April $10^{\text {th }}$, 2017, Acceptance Date: July $26^{\text {th }}$, 2017, Publication Date: July $31^{\text {st }}, 2017$

Citation: Ashaolu T.J., Yupanqui C.T., Suppressive activity of enzymatically-educed soy protein hydrolysates on degranulation in IgE-antigen complex-stimulated RBL-2H3 cells. Functional Foods in Health and Disease 2017; 7(7): 545-561. https://doi.org/10.31989/ffhd.v7i7.356

\begin{abstract}
Background: Soy protein isolate (SPI) is increasingly used in foods because it is a high quality non-dairy protein with excellent functional properties. However, soy allergy is one of the world's major eight food allergies.
\end{abstract}

Objective: To investigate the anti-allergic activity of soy protein hydrolysates (SPHs) produced with alcalase and pepsin proteases.

Methods: SPI was enzymatically hydrolysed using the proteases, while evaluating the reaction conditions which include E/S (enzyme to substrate ratio) of $0.5 \%, 1.0 \%$ and $1.5 \%(250 \mathrm{u} / \mathrm{mg}$ and $5 \mathrm{u} / \mathrm{g}$ of pepsin and alcalase respectively); and hydrolysis time ( $0 \mathrm{~min}, 30 \mathrm{~min}, 1 \mathrm{~h}, 2 \mathrm{~h}, 4 \mathrm{~h}$ and $8 \mathrm{~h}$ ). Afterwards, rat basophilic leukaemia (RBL)-2H3 cells activated by the IgE-antigen complex were used to assess mast cell degranulation inhibitory activity of the SPHs by the release of $\beta$ hexosaminidase. RBL-2H3 cells were sensitized with monoclonal anti-dinitrophenol (DNP) specific IgE and challenged with the antigen DNP-bovine serum albumin in the presence or absence of SPHs.

Results: It was observed that $0.1 \mathrm{mg} / \mathrm{mL}$ concentration of the $0.5 \% \mathrm{E} / \mathrm{S}$ SPHs prepared in the first 4h significantly $(\mathrm{P}<0.05)$ inhibited $\beta$-hexosaminidase release in an IgE-antigen complexstimulated RBL-2H3 cells compared to those produced at other time intervals, E/S, and concentrations. 
Conclusion: This is the first report of its kind that shows the ability of SPHs to suppress degranulation of RBL-2H3 cells. Consequently, SPHs have good prospects to be used as potential sources of low cost hypo or anti-allergic protein.

Keywords: Soy Protein Isolate, Soy Protein Hydrolysates, RBL-2H3 Cells, $\beta$-Hexosaminidase, Anti-allergy

\section{INTRODUCTION}

It is estimated that in the industrialized world every one in three people have allergies [1]. A food allergy is an immunological response to food, whether IgE-mediated or not. The mechanisms involved in allergy includes the exposure of linear protein to Th2 cells by the antigen-presenting cells (APC), thereby stimulating B cells to release antigen-specific IgE to bind the target antigen surface. Afterwards, mast cells bind to the receptors of IgEs produce and become degranulated in order to release histamines and other mediators such as cytokines, granulocyte macrophage colony-stimulating factor (GM-CSF), leukotrienes, heparin, and many proteases into the environment [2]. These chemical mediators cause the characteristic symptoms of allergies. Due to the entrapment of $\beta$-hexosaminidase in the granules, its release is used as a suitable marker for the degree of degranulation [3]. Food allergens are generally proteins mediated by IgE. Based on the primary structure of proteins, which may be linear or sequential, the portion of the protein recognized by IgE is called the epitope [4]. IgEs, which bind to epitopes that have sequential amino acids, are associated with persistence of allergy compared to epitopes dependent on folding conformations [5]. However, the biological properties of proteins are significantly dependent on the three dimensional (3D) or tertiary structure, which can be disrupted by certain food processing methods such as chemical hydrolysis or thermal treatments. Enzymatic hydrolysis of food proteins is preferred in order to avoid the decimation of certain amino acids like cysteine, tryptophan, and serine, which may cause subsequent loss of biological activity [6].

Soy protein isolate (SPI) is increasingly used in foods as functional and nutritional ingredients and as a substitute for animal-derived proteins from milk, meat, and eggs because it is a high quality non-diary protein with excellent functional properties. It is a vegetable protein which can be employed in food products due to its good water and fat holding capacity. However, soy allergy is one of the major food allergies posing global concerns. The Food Allergy Research and Education institute [7] has reported that soy allergy is one of the eight most common food allergies worldwide of which children are mostly affected. $0.4 \%$ of children are allergic to the soy protein used in their nutrition formula [8], with many vegetarians considering soy as their alternative to meat. At least 16 IgE-binding soy proteins with molecular masses ranging from 7.5 to $97 \mathrm{kDa}$ have been characterized as being involved in clinical allergy with storage proteins Gly m5 (bconglycinin) and Gly m6 (glycinin) identified as the major allergen-containing components [9, 10]. Therefore, protein structural modification techniques that can help eliminate soy protein allergenicity are of paramount importance [11]. These techniques often involve acidic, alkaline, and enzymatic treatments among others. Enzymatic hydrolysis of SPI involves proteolytic enzymes such as pomiferin, cucurbita, pepsin, papain, chymotrypsin [12], novozym, flavourzyme [13], alcalase, neutrase, and corolase [14]. These enzymes have been used synergistically to attain limited or extended degrees of hydrolysis. Alcalase has become predominant in several reports due to its higher degree of hydrolysis values [15-17] and assessment of the digestibility of proteins. Pepsin has either been rarely or singly used in all the previous reports, and is among some of the most important digestive enzymes found in mammals including humans, thereby making it an important enzyme for studying the gastro-intestinal tract digestion process. Enzymatic hydrolysis of proteins results in smaller molecular mass with less secondary structure and in some cases 
improved functional properties compared to the intact protein [18]. Moreover, the hydrolysates are physiologically better than intact proteins because their intestinal absorption appears to be more effective due to the increase of solubility [19].

As a result, soy protein hydrolysates (SPHs) have been reported to exhibit various physiological activities which include hypolipidaemic and hypocholesterolemic properties [20], antioxidant activity [21], reduction of blood pressure [22], improvement in both arterial compliance and endothelial function [23], insulin resistance, and weight loss in obesity [24]. SPHs have also been used as clinical products, such as infant formulas and hospital diets for patients in addition to food substitutes [25]. However, the anti-allergic activity of soy protein hydrolysates prepared with one or several proteases, and evaluated with RBL-2H3 cells have not been investigated systematically until now. In this study, we were prompted to investigate the antiallergic activity of alcalase and pepsin-educed SPHs, taking into consideration different enzyme to substrate ratio concentrations $(\mathrm{E} / \mathrm{S})$ of $0.5 \%, 1.0 \%$, and $1.5 \%$; and hydrolysis time intervals of $0 \mathrm{~min}, 30 \mathrm{~min}, 1 \mathrm{~h}, 2 \mathrm{~h}, 4 \mathrm{~h}$, and $8 \mathrm{~h}$ respectively. SPI was enzymatically hydrolysed using commercially available proteases, alcalase, and pepsin, while evaluating these reaction conditions. Thereafter, mast cell degranulation inhibitory activity of the SPHs by the release of $\beta$ hexosaminidase from RBL-2H3 cells was investigated at equal concentrations of $0.1 \mathrm{mg} / \mathrm{mL}, 1.0$ $\mathrm{mg} / \mathrm{mL}$, and $10 \mathrm{mg} / \mathrm{mL}$ in order to ascertain the effective doses of the prepared SPHs. This is the first report of its kind that shows the ability of SPHs to suppress degranulation of RBL-2H3 cells, and thereby has a high prospect to be used as a potential source of low cost hypo or anti-allergic protein.

\section{MATERIALS AND METHODS}

\section{Materials}

Food grade SPI (protein content $90.2 \%$ dry base) was purchased from Wachsen Industry Company, Ltd (Qingdao, China). Alcalase (5 U/g) and pepsin $(250 \mathrm{U} / \mathrm{mg}$ ) respectively were purchased from Sigma Co. (St. Louis, MO, USA). All other chemicals used were of the highest analytical grade commercially available.

\section{Enzymatic hydrolysis}

Hydrolysis with alcalase and pepsin was performed at optimum $\mathrm{pH}$ and temperature according to previous literature reviews $[15,26]$. See Table 1.

Table 1. Parameters used for the enzymatic hydrolysis of soy protein isolate

\begin{tabular}{lll}
\hline Parameters & Conditions & Conditions \\
\hline Enzymes & Alcalase & Pepsin \\
Enzyme concentration & $0.5,1.0$ and $1.5 \%$ & $0.5,1.0$ and $1.5 \%$ \\
Reaction time & $0.5,1,2,4,8$ hours & $0.5,1,2,4,8$ hours \\
pH & 8.0 & 2.0 \\
Temperature & $50^{\circ} \mathrm{C}$ & $37^{\circ} \mathrm{C}$ \\
\hline
\end{tabular}

\section{Preparation of soy protein hydrolysates}

SPI was dissolved in deionized water in the ratio of 1:8 (w/v) for both alcalase-treated and pepsintreated samples. Hydrolysis of SPI with alcalase and pepsin was achieved at $50{ }^{\circ} \mathrm{C}$ and $37{ }^{\circ} \mathrm{C}$, using $2 \mathrm{M} \mathrm{NaOH}$ and $2 \mathrm{M} \mathrm{HCl}$ at the $\mathrm{pH}$ of 8.0 and 2.0 respectively. Enzyme-substrate ratios used were 
$0.5 \%, 1.0 \%$, and $1.5 \% / 100 \mathrm{~g}$ substrate. The SPI was pre-incubated for $15 \mathrm{~min}$ at respective optimum enzymatic temperatures prior to hydrolysis process. The hydrolysis time was set up to $8 \mathrm{~h}$. The hydrolysate samples were taken at $0 \mathrm{~min}, 30 \mathrm{~min}, 1 \mathrm{~h}, 2 \mathrm{~h}, 4 \mathrm{~h}$, and $8 \mathrm{~h}$ intervals, for future analysis. Each enzyme was inactivated using heat treatment at $95{ }^{\circ} \mathrm{C}$ for $15 \mathrm{~min}$ in a thermostatcontrolled water bath. Afterwards, the samples were cooled on ice to room temperature and centrifuged at $4{ }^{\circ} \mathrm{C}, 10,000 \mathrm{rpm}$ for $20 \mathrm{~min}$, to separate the supernatant from the pellet. Finally, the supernatant (soy protein hydrolysates) was lyophilized and stored at $-20^{\circ} \mathrm{C}$. Fig. 1 shows the production flow chart.

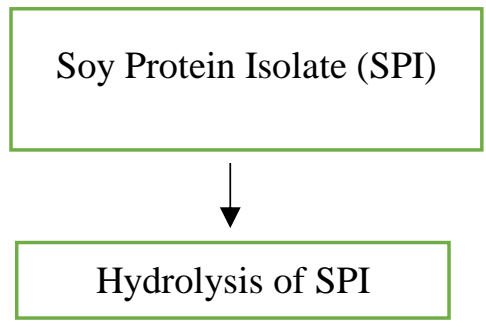

E/S: $0.5 \%, 1.0 \% \& 1.5 \%$; Time: $30 \mathrm{~min}, 1 \mathrm{~h}, 2 \mathrm{~h}, 4 \mathrm{~h} \& 8 \mathrm{~h}$

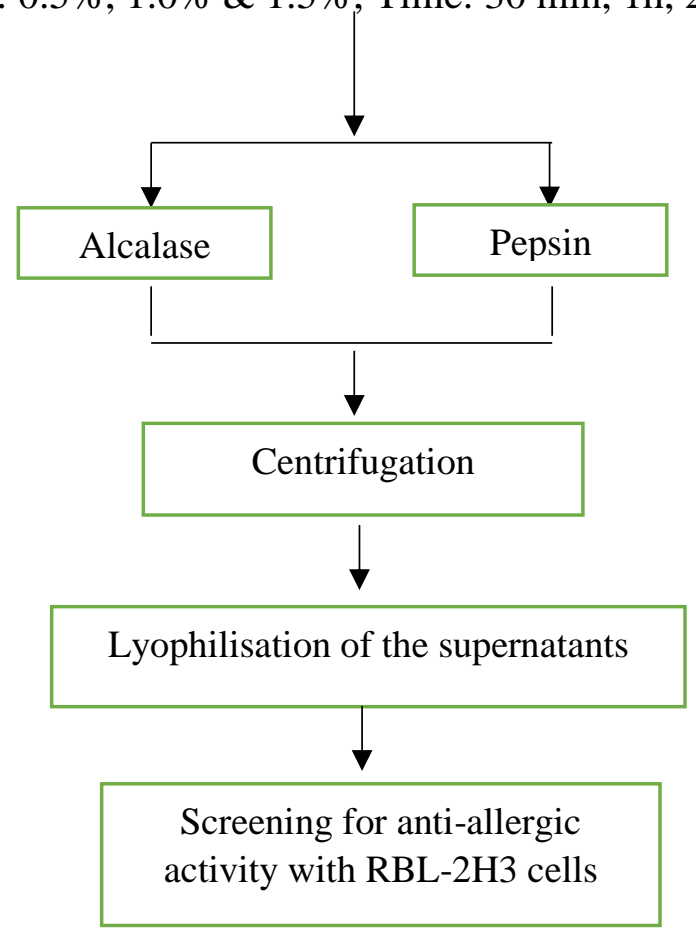

Figure 1. Flow chart showing the production of soy protein hydrolysates using alcalase and pepsin

\section{Degree of hydrolysis $(\mathrm{DH})$}

The DH of hydrolysates samples obtained was analyzed based on the availability of free amino group upon hydrolysis, with OPA (o-phthaldialdehyde) reagent. The degree of hydrolysis was carried out according to the method of Nielsen and their colleagues [27]. $400 \mu \mathrm{L}$ of SPHs was added to $3 \mathrm{~mL}$ of freshly prepared OPA solution. The solution was immediately mixed for 5 seconds and incubated for $2 \mathrm{~min}$ at room temperature. The absorbance was measured at $340 \mathrm{~nm}$ using UV-vis spectrophotometer (Genesys 10 series., Madison, WI, USA). The amount of free amino acid groups in the SPHs was calculated as serine $-\mathrm{NH}_{2}$ using $\mathrm{L}$-serine as a standard. The total number of $\alpha$-amino nitrogen in the sample was determined by acid hydrolysis (complete hydrolysis) of sample in $6 \mathrm{~N} \mathrm{HCl}$, at $110{ }^{\circ} \mathrm{C}$ for $24 \mathrm{hr}$. The percentage degree of hydrolysis (\% $\mathrm{DH})$ was calculated using the following equation: 
Where:

$\% \mathrm{DH}=\left(\left[\mathrm{NH}_{2}\right]_{\mathrm{Tx}}-\left[\mathrm{NH}_{2}\right]_{\mathrm{T} 0}\right) \times 100$

$\left(\left[\mathrm{NH}_{2}\right]_{\text {Total }}-\left[\mathrm{NH}_{2}\right]_{\mathrm{T} 0}\right.$

$\left[\mathrm{NH}_{2}\right]_{\mathrm{T} 0}=$ amount of free $-\mathrm{NH}_{2}$ groups at $0 \mathrm{~min}$ of hydrolysis $(\mathrm{mg} / \mathrm{mL})$

$\left[\mathrm{NH}_{2}\right]_{\mathrm{Tx}}=$ amount of free $-\mathrm{NH}_{2}$ groups in the supernatant after $\times$ min of point protease hydrolysis for each experiment $(\mathrm{mg} / \mathrm{mL})$

$\left[\mathrm{NH}_{2}\right]_{\text {Total }}=$ amount of $-\mathrm{NH}_{2}$ groups resulting from acid hydrolysis after $24 \mathrm{~h}(\mathrm{mg} / \mathrm{mL})$

\section{Protein recovery of SPHs}

Protein recovery protocol of the Kjeldahl method [28] was implemented, and was calculated as the amount of protein $(\% \mathrm{~N} \times 6.25)$ present in the hydrolysates relative to the initial amount of protein present in the reaction mixture [15].

\section{B-hexosaminidase release assay}

Modified method of Matsuda and colleagues [29] was used. Anti-DNP IgE, DNP-BSA and $\rho$ nitrophenyl N-acetyl- $\beta$-D-glucosaminide (PNAG) were purchased from Sigma (USA). The rat basophilic leukemia RBL-2H3 cells were purchased from American Type Culture Collection (ATCC CRL-2256, VA, USA). The cells were cultured in Eagle's minimum essential medium (EMEM) supplemented with $15 \%$ (v/v) fetal bovine serum (FBS) and 1.25\% Pen-Strep (a mixture of $10,000 \mathrm{U} / \mathrm{mL}$ penicillin and $10,000 \mu \mathrm{g} / \mathrm{mL}$ streptomycin; purchased from Gibco Co. (Grand Island, NY, USA) at $37{ }^{\circ} \mathrm{C}$ in a humidified, $\mathrm{CO}_{2}$-controlled (5\%) incubator. Briefly, RBL-2H3 cells was cultured in 24-well plates at a concentration of $2 \times 10^{5}$ cells/well using Eagle's Minimal Essential Medium containing FBS (15\%), penicillin (100 units $/ \mathrm{mL})$, streptomycin (100 units/mL), and $40 \mu \mathrm{L}$ anti-DNP $\operatorname{IgE}(50 \mu \mathrm{g} / \mathrm{mL})$. The plate was incubated overnight at $37{ }^{\circ} \mathrm{C}$ in $5 \% \mathrm{CO}_{2}$ for sensitization of the cells. The cells were washed twice with $200 \mu \mathrm{L}$ of Siraganian buffer $[119 \mathrm{mM}$ $\mathrm{NaCl}, 5 \mathrm{mM} \mathrm{KCl}, 5.6 \mathrm{mM}$ glucose, $0.4 \mathrm{mM} \mathrm{MgCl} 2,1 \mathrm{mM} \mathrm{CaCl} 2,25 \mathrm{mM}$ piperazine- $N$, $N$ '-bis (2ethanesulfonic acid) (PIPES), 0.1\% bovine serum albulmin (BSA), and $40 \mathrm{mM} \mathrm{NaOH}, \mathrm{pH} 7.2]$ and then incubated in $160 \mu \mathrm{L}$ of Siraganian buffer for an additional $10 \mathrm{~min}$ at $37{ }^{\circ} \mathrm{C}$. Afterwards, $20 \mu \mathrm{L}$ of $0.1 \mathrm{mg} / \mathrm{mL}, 1.0 \mathrm{mg} / \mathrm{mL}$, and $10 \mathrm{mg} / \mathrm{mL}$ of the test sample (SPHs solutions prepared with PBS buffer) were added to each well and incubated for $20 \mathrm{~min}$, followed by the addition of $20 \mu \mathrm{L}$ of antigen (DNP-BSA, final concentration was $10 \mu \mathrm{g} / \mathrm{mL}$ ) at $37^{\circ} \mathrm{C}$ for $20 \mathrm{~min}$. This step stimulates the cells to degranulate. The supernatant was transferred into 96-well plate and incubated with 50 $\mu \mathrm{L}$ of substrate ( $1 \mathrm{mM} p$-nitrophenyl- $N$-acetyl- $\beta$-D-glucosaminide) in $0.1 \mathrm{M}$ citrate buffer ( $\mathrm{pH} 4.5)$ at $37{ }^{\circ} \mathrm{C}$ for $2 \mathrm{~h}$. The reaction was stopped by adding $200 \mu \mathrm{L}$ of stop solution $(0.1 \mathrm{M}$ $\mathrm{Na}_{2} \mathrm{CO}_{3} / \mathrm{NaHCO}_{3}, \mathrm{pH} 10.0$ ). The absorbance was measured with a microplate reader at $405 \mathrm{~nm}$ within $30 \mathrm{~min}$. A similar experiment was also set up for Ketotifen fumarate, as the standard. The inhibition of $\beta$-hexosaminidase release $(\%)$ by both the test and standard samples was calculated by the following equation:

$\%$ Inhibition $=[1-(\mathrm{T}-\mathrm{B}) /(\mathrm{C}-\mathrm{B})] \times 100$.

Where:

Control $(\mathrm{C})=$ DNP-BSA $(+)$, Test sample (-)

Test $(\mathrm{T})=$ DNP-BSA $(+)$, Test sample $(+)$

Blank $(\mathrm{B})=$ DNP-BSA $(-)$, Test sample $(+)$

Normal $(\mathrm{N})=$ DNP-BSA $(-)$, Test sample $(-)$ 


\section{Cell proliferation assay}

The activity of SPHs on cell survival was evaluated by 3-(3,5-dimethylthiazol-2-yl) -2,5diphenyltetrazolium bromide (MTT) colorimetric assay. RBL-2H3 cells $(5 \times 105 /$ well $)$ were cultured in 24-well plates. After growth in E-MEM containing $15 \% \mathrm{FBS}$ at $37{ }^{\circ} \mathrm{C}$ and $5 \% \mathrm{CO} 2$ overnight, $0.1 \mathrm{mg} / \mathrm{ml}, 1.0 \mathrm{mg} / \mathrm{ml}$, and $10 \mathrm{mg} / \mathrm{ml}$ concentrations of the test samples (SPHs) were added to the plates, and incubated for $4 \mathrm{~h}$ with $200 \mu \mathrm{L} \mathrm{MTT}(5 \mathrm{mg} / \mathrm{mL})$. After incubation, the supernatant was removed and the resultant precipitate was dissolved with $200 \mu \mathrm{L}$ DMSO. The absorbance was measured at $570 \mathrm{~nm}$. The cell viability (\%) was calculated by the following equation:

$$
\% \text { Viability }=100-[(\mathrm{C}-\mathrm{T} / \mathrm{C}) \times 100]
$$

Where:

$$
\begin{aligned}
& \text { Control }(\mathrm{C})=\text { Control; DNP-BSA }(+) \\
& \text { Test }(\mathrm{T})=\text { Test; DNP-BSA }(+) \text {, Test sample }(+)
\end{aligned}
$$

Amino acid profile of SPHs

Soy protein hydrolysates with the most potent anti-allergic activity was sent to Central laboratory Thai (Songkla, Thailand) for amino acid composition analysis. The amino acid profile was determined by hydrolyzing $1 \mathrm{mg}$ of the SPH sample with $6 \mathrm{~mol} / \mathrm{L} \mathrm{HCl}$ at $110 \mathrm{oC}$ for $20 \mathrm{~h}$ under vacuum. Afterwards, the hydrolysate was evaporated to dryness under vacuum. The dried sample was dissolved in $200 \mu \mathrm{L}$ of borax buffer and centrifuged. $100 \mu \mathrm{L}$ of the resultant supernatant was loaded onto an Agilent 1100 LC/MSD Model G1946D with Phenomenex (C18) $250 \times 2 \mathrm{~mm}$ column (Agilent Technologies, Palo Alto, CA, USA) at 40 oC with o-phthalaldehyde/3mercaptopropionate/9-fluorenylmethylchloroformate pre-column derivatization and diode array detector.

\section{Statistical analysis}

Data are expressed as the mean \pm standard deviation (SD), being the average of three samples per experiment. Analyses were performed using SPSS software version 17.0. The experiment was repeated at least thrice to confirm the results. The level of statistical significance, using analysis of variance (ANOVA) with Tukey's test, was set to $\mathrm{p}<0.05$.

\section{RESULTS AND DISCUSSION}

\section{Enzymatic hydrolysis of SPI}

Protein hydrolysates are meant to provide nutritional benefits to different classes of consumers and patients in contrast to crude proteins. The production of extensive protein hydrolysates by varying proportions of the enzyme in use is invariably an effective way to obtain protein hydrolysates with defined characteristics. DH is a measure of the extent of hydrolytic degradation of a protein, and is the most widely used indicator for comparison among different proteolysis process [15]. Fig. 2 (a) shows the hydrolysis curves obtained by hydrolysing SPI with alcalase under hydrolysis conditions of $\mathrm{E} / \mathrm{S}=0.5,1.0$, and $1.5 \% ; \mathrm{pH} 8.0, \mathrm{~T}=50 \mathrm{oC}$ and $\mathrm{t}=0 \mathrm{~min}, 30 \mathrm{~min}, 1 \mathrm{~h}, 2 \mathrm{~h}, 4 \mathrm{~h}$, and $8 h$. 

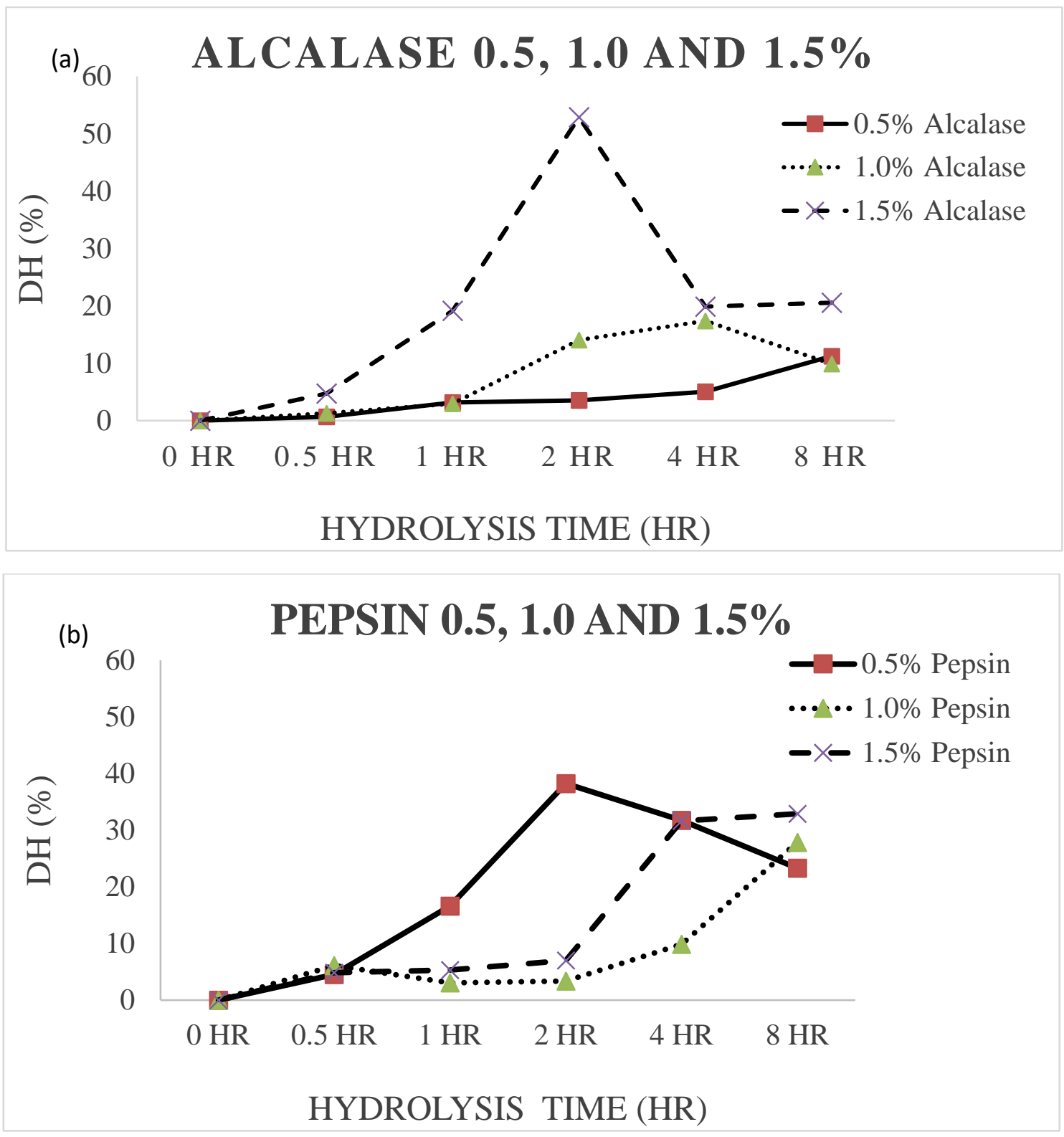

Figure 2. Enzymatic hydrolysis of soy protein isolate with:

(a) Alcalase at $50{ }^{\circ} \mathrm{C}, \mathrm{pH} 8.0$ and time intervals of $0-8 \mathrm{~h}$.

(b) Pepsin at $37^{\circ} \mathrm{C}, \mathrm{pH} 2.0$ and time intervals of $0-8 \mathrm{~h}$.

All hydrolytic curves showed an increasing rate of hydrolysis, with $1.5 \% \mathrm{E} / \mathrm{S}$ attaining the highest rate in the first $2 \mathrm{~h}(52.87 \%)$, but the proteolysis rate decreased gradually over time. AdlerNissen [30] attributed the reduction in hydrolysis rate to the competition between unhydrolysed protein and the peptides being constantly formed during hydrolysis. Xiang et al [15] experienced a vivid change after $180 \mathrm{~min}$ (3h) of hydrolysis of SPI with alcalase, which also gave the highest $\mathrm{DH}$ value of $18.36 \%$ at the concentration of $2.5 \% \mathrm{E} / \mathrm{S}$. The highest concentration in this experiment obtained at $1.5 \% \mathrm{E} / \mathrm{S}(52.87 \%)$ did not confer any substantial anti-allergic activity but the lowest concentration $(0.5 \%)$ did. Alcalase has been used not only for the production of protein hydrolysates with better functional and nutritional characteristics but also for the generation of bioactive peptides with ACE inhibitory activity [31].

The highest degree of hydrolysis of soy protein hydrolysates so far recorded until date is 39.5\% [13], while most other scientists detected a rate between 1-25\% [32]. However, in Fig.2 (b), the degree of hydrolysis obtained from pepsin was much higher $(38.24 \%)$ at a lower protease 
concentration of $0.5 \%$, compared to $\mathrm{DH}(3.54 \%)$ attained by alcalase and at same time (2h). This suggests that enzyme type affects the degree of protein hydrolysis in addition to the functionality/activity of such hydrolysate as further confirmed with the cell line (RBL-2H3) antiallergy test. Moreover, other SPHs treated with pepsin concentrations of $1.0 \%$ and $1.5 \%$ revealed the possibility of increasing yield of hydrolysis after the first $2 \mathrm{~h}$.

\section{Protein recovery of SPHs}

Higher DH indicates more hydrolysed soy protein could be obtained. The yields of protein hydrolysates with different concentrations of alcalase and pepsin are presented in Table 2. Although many factors can affect the yield of hydrolysis, the concentration and type of enzyme used contributed significantly to the yield and anti-allergic property of the final product. High protein recovery by alcalase-treated and pepsin-treated SPHs (87.70\% and $89.30 \%$ respectively) at $0.5 \% \mathrm{E} / \mathrm{S}$ makes prospective commercial applications cost effective.

Protein recovery was measured as the amount of protein $(\% \mathrm{~N} \times 6.25)$ present in the hydrolysates relative to the initial amount of protein present in the reaction mixture. Data are reported as the means $\pm \mathrm{SD}, \mathrm{n}=3$

Table 2. Protein recovery from SPHs subjected to different hydrolysis conditions

\begin{tabular}{|c|c|c|c|c|}
\hline \multirow{2}{*}{$\begin{array}{l}\text { Enzyme } \\
(\%)\end{array}$} & \multirow[t]{2}{*}{ concentration } & \multirow{2}{*}{ Time (Hour) } & \multicolumn{2}{|c|}{ Protein recovery } \\
\hline & & & (\%)-Alcalase & (\%)-Pepsin \\
\hline \multirow[t]{6}{*}{0.5} & & 0 & $73.71 \pm 0.002$ & $71.75 \pm 0.011$ \\
\hline & & 0.5 & $75.60 \pm 0.001$ & $82.64 \pm 0.019$ \\
\hline & & 1 & $85.50 \pm 0.003$ & $88.62 \pm 0.007$ \\
\hline & & 2 & $86.37 \pm 0.001$ & $60.68 \pm 0.006$ \\
\hline & & 4 & $87.70 \pm 0.013$ & $86.66 \pm 0.002$ \\
\hline & & 8 & $86.02 \pm 0.001$ & $89.30 \pm 0.021$ \\
\hline \multirow[t]{6}{*}{1.0} & & 0 & $76.95 \pm 0.029$ & $73.51 \pm 0.002$ \\
\hline & & 0.5 & $85.90 \pm 0.007$ & $83.69 \pm 0.000$ \\
\hline & & 1 & $85.79 \pm 0.011$ & $85.97 \pm 0.004$ \\
\hline & & 2 & $85.18 \pm 0.001$ & $87.19 \pm 0.003$ \\
\hline & & 4 & $85.81 \pm 0.004$ & $84.92 \pm 0.004$ \\
\hline & & 8 & $86.76 \pm 0.015$ & $84.93 \pm 0.004$ \\
\hline \multirow[t]{6}{*}{1.5} & & 0 & $76.95 \pm 0.029$ & $73.89 \pm 0.003$ \\
\hline & & 0.5 & $85.90 \pm 0.007$ & $84.22 \pm 0.003$ \\
\hline & & 1 & $85.79 \pm 0.011$ & $84.22 \pm 0.001$ \\
\hline & & 2 & $85.18 \pm 0.001$ & $85.79 \pm 0.003$ \\
\hline & & 4 & $85.81 \pm 0.004$ & $86.67 \pm 0.007$ \\
\hline & & 8 & $86.76 \pm 0.015$ & $85.79 \pm 0.004$ \\
\hline
\end{tabular}


Ability of SPHs to inhibit $\beta$-hexosaminidase release by IgE-antigen complex-stimulated RBL$2 \mathrm{H3}$ cells and their proliferation

To the best of our knowledge, anti-allergic activity of soy protein hydrolysates using RBL-2H3 cells has not been reported yet in previous studies despite its excellent functional properties and uses in food and meat industries. In order to investigate the ability of SPHs to inhibit degranulation, RBL-2H3 cells were primed with anti-DNP IgE, treated with SPHs, stimulated with DNP-BSA, and afterwards measured the release of $\beta$-hexosaminidase. As shown in Table 3-4, stimulation with the IgE-antigen complex induced the release of $\beta$-hexosaminidase, which was significantly inhibited $(39.22 \%, \mathrm{P}<0.05)$ by alcalase-educed SPHs at the conditions of $0.5 \% \mathrm{E} / \mathrm{S}, 4 \mathrm{~h}$ of hydrolysis using $0.1 \mathrm{mg} / \mathrm{mL}$ concentration as compared to other conditions. Other concentrations of E/S as well as the time differences did not yield any significant inhibitory results. Interestingly, SPHs prepared with pepsin showed more promise, as there was a much stronger inhibitory effect $(72.51 \%)$ at the same conditions $(0.5 \% \mathrm{E} / \mathrm{S}$, $4 \mathrm{~h}$ of hydrolysis using $0.1 \mathrm{mg} / \mathrm{mL}$ concentration) compared to SPHs treated with alcalase (39.22\%). Other E/S concentrations of pepsin-educed SPHs as well as the time differences also yielded more significant inhibitory results than SPHs prepared with alcalase.

Rat basophilic leukaemia RBL-2H3 cells are mucosal mast cells that have been used more often in the study of anti-allergic activity of diverse functional food products or medicines. When RBL-2H3 cells are primed with anti-DNP IgE, stimulation with an antigen such as DNP-BSA induces them to rapidly degranulate and produce cytokines, including histamines [33]. $\beta$ hexosaminidase is stored in the secretory granules of RBL-2H3 cells and is released simultaneously with histamine when the cells are immunologically activated, it is therefore generally accepted that $\beta$-hexosaminidase is a degranulation marker of mast cells and can reflect changes in other inflammatory factors [34]. RBL-2H3 cells were exposed to various enzyme concentrations of alcalase-educed SPHs ranging from $0.5 \%$ to $1.5 \% \mathrm{E} / \mathrm{S}$ for $4 \mathrm{~h}$. As shown in Table $3-4$, RBL-2H3 cell viability was not affected by the $0.1 \mathrm{mg} / \mathrm{mL}$ concentration of SPHs obtained from different time and E/S intervals, except for a slight cytotoxic effect demonstrated by increasing $\mathrm{E} / \mathrm{S}$ concentrations in pepsin-educed hydrolysates. However, if cell survival is more than $80 \%$, it is considered non-cytotoxic [35,36]. The results obtained also support the hypothesis that hydrolysed proteins and peptides demonstrate better bioactive activity than their parent proteins [37]. Some reports have already been made on certain biological activities such as antioxidant, anti-thrombotic, angiotensin-converting enzyme (ACE) inhibition, antihypertensive, and immunomodulatory properties for soy peptides [24, 38-39]. Xiang et al [15] also evaluated immunoregulatory properties of SPHs prepared with alcalase and insoluble soy protein, only to find out that apart from being more efficacious than other enzymes, they had the highest immunomodulatory activity on proliferation of murine splenic lymphocytes and phagocytic effect of peritoneal macrophages. However, in this research, pepsin has been employed in the production of SPHs without any interference from other enzymes and has been discovered to exhibit antiallergic activity. 
Table 3. Inhibition rate of $\beta$-hexosaminidase release by SPHs obtained from different hydrolysis conditions of alcalase with regard to E/S and time

\begin{tabular}{|c|c|c|c|c|c|c|c|c|c|c|}
\hline & $0.001 \mathrm{mg} / \mathrm{ml}$ & & $0.01 \mathrm{mg} / \mathrm{ml}$ & & $0.1 \mathrm{mg} / \mathrm{ml} \mathrm{SPH}$ & & $1.0 \mathrm{mg} / \mathrm{ml} \mathrm{SPH}$ & & $10.0 \mathrm{mg}$ & \\
\hline $\begin{array}{l}\text { E/S } \underset{\text { S }}{\&} \text { Time } \\
\text { Conditions }\end{array}$ & $\%$ Inh & $\%$ prolif & $\%$ Inh & $\%$ prolif & $\%$ Inh & $\%$ prolif & $\%$ Inh & $\%$ prolif & $\%$ Inh & $\%$ prolif \\
\hline \multicolumn{11}{|l|}{$0.5 \%$ Alc } \\
\hline $0 \mathrm{~min}$ & & & & & $8.67 \pm 0.357$ & $100.01 \pm 0.068$ & - & $97.93 \pm 0.017$ & - & $96.06 \pm 0.022$ \\
\hline $30 \mathrm{~min}$ & & & & & - & $100.64 \pm 0.069$ & - & $90.69 \pm 0.006$ & - & $91.61 \pm 0.020$ \\
\hline $1 \mathrm{~h}$ & & & & & - & $101.92 \pm 0.072$ & - & $92.02 \pm 0.006$ & - & $104.42 \pm 0.005$ \\
\hline $2 \mathrm{~h}$ & & & & & - & $104.24 \pm 0.073$ & - & $92.70 \pm 0.014$ & - & $90.07 \pm 0.022$ \\
\hline $4 \mathrm{~h}$ & & & & & $39.22 \pm 0.207$ & $92.07 \pm 0.053$ & $33.22 \pm 0.014^{*}$ & $102.96 \pm 0.006$ & - & $102.99 \pm 0.031$ \\
\hline $8 \mathrm{~h}$ & & & & & - & $103.65 \pm 0.069$ & - & $97.08 \pm 0.006$ & - & $95.49 \pm 0.017$ \\
\hline K. fumarate & $53.77 \pm 0.007^{*}$ & $87.48 \pm 0.007$ & $58.92 \pm 0.002^{*}$ & $87.67 \pm 0.008$ & $108.22 \pm 0.004^{*}$ & $89.51 \pm 0.003$ & & & & \\
\hline \multicolumn{11}{|l|}{$1.0 \%$ Alc } \\
\hline $0 \mathrm{~min}$ & & & & & - & $106.53 \pm 0.069$ & - & $99.45 \pm 0.006$ & - & $103.93 \pm 0.009$ \\
\hline $30 \min$ & & & & & - & $99.89 \pm 0.070$ & - & $94.58 \pm 0.014$ & - & $93.49 \pm 0.034$ \\
\hline $1 \mathrm{~h}$ & & & & & $25.38 \pm 0.228$ & $97.97 \pm 0.058$ & $22.29 \pm 0.014^{*}$ & $93.80 \pm 0.014$ & - & $96.48 \pm 0.039$ \\
\hline $2 \mathrm{~h}$ & & & & & - & $96.41 \pm 0.057$ & - & $89.76 \pm 0.008$ & - & $91.56 \pm 0.016$ \\
\hline $4 \mathrm{~h}$ & & & & & - & $101.72 \pm 0.070$ & - & $91.84 \pm 0.004$ & - & $99.42 \pm 0.003$ \\
\hline $8 \mathrm{~h}$ & & & & & - & $99.09 \pm 0.074$ & - & $96.41 \pm 0.012$ & - & $79.26 \pm 0.006$ \\
\hline \multicolumn{11}{|l|}{$1.5 \%$ Alc } \\
\hline $0 \mathrm{~min}$ & & & & & - & $101.45 \pm 0.071$ & - & $97.84 \pm 0.017$ & - & $108.07 \pm 0.026$ \\
\hline $30 \mathrm{~min}$ & & & & & - & $100.37 \pm 0.074$ & - & $101.87 \pm 0.004$ & - & $104.42 \pm 0.020$ \\
\hline $1 \mathrm{~h}$ & & & & & - & $98.98 \pm 0.090$ & - & $98.63 \pm 0.016$ & - & $108.04 \pm 0.037$ \\
\hline $2 \mathrm{~h}$ & & & & & - & $99.88 \pm 0.071$ & - & $96.84 \pm 0.010$ & - & $96.90 \pm 0.024$ \\
\hline $4 \mathrm{~h}$ & & & & & - & $97.91 \pm 0.067$ & - & $97.33 \pm 0.014$ & - & $99.52 \pm 0.013$ \\
\hline $8 \mathrm{~h}$ & 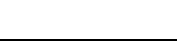 & & & & - & $92.50 \pm 0.078$ & - & $93.27 \pm 0.020$ & - & $89.98 \pm 0.018$ \\
\hline
\end{tabular}


Table 4. Inhibition rate of $\beta$-hexosaminidase release by SPHs obtained from different hydrolysis conditions of pepsin with regard to E/S and time

\begin{tabular}{|c|c|c|c|c|c|c|c|c|c|c|}
\hline & $0.001 \mathrm{mg} / \mathrm{ml}$ & & $0.01 \mathrm{mg} / \mathrm{ml}$ & & $0.1 \mathrm{mg} / \mathrm{ml} \mathrm{SPH}$ & & $1.0 \mathrm{mg} / \mathrm{ml} \mathrm{SPI}$ & & $10.0 \mathrm{mg} / \mathrm{ml} \mathrm{SF}$ & \\
\hline $\begin{array}{l}\text { E/S \& Time } \\
\text { Conditions }\end{array}$ & $\%$ Inh & $\%$ Prolif & $\%$ Inh & $\%$ Prolif & $\%$ Inh & $\%$ prolif & $\%$ Inh & $\%$ prolif & $\%$ Inh & $\%$ prolif \\
\hline \multicolumn{11}{|l|}{ 0.5\% Pepsin } \\
\hline $0 \mathrm{~min}$ & & & & & $36.55 \pm 0.014^{*}$ & $94.14 \pm 0.075$ & - & $101.00 \pm 0.023$ & - & $86.24 \pm 0.009$ \\
\hline $30 \min$ & & & & & $59.06 \pm 0.012^{*}$ & $99.56 \pm 0.075$ & $66.37 \pm 0.007^{*}$ & $94.43 \pm 0.024$ & - & $86.09 \pm 0.012$ \\
\hline $1 \mathrm{~h}$ & & & & & - & $96.34 \pm 0.077$ & $69.30 \pm 0.016^{*}$ & $92.64 \pm 0.017$ & - & $81.17 \pm 0.019$ \\
\hline $2 \mathrm{~h}$ & & & & & - & $102.75 \pm 0.094$ & - & $90.12 \pm 0.010$ & - & $90.28 \pm 0.028$ \\
\hline $4 \mathrm{~h}$ & & & & & $72.51 \pm 0.012^{*}$ & $95.95 \pm 0.065$ & - & $98.83 \pm 0.021$ & $25.53 \pm 0.012^{*}$ & $95.94 \pm 0.017$ \\
\hline $8 \mathrm{~h}$ & & & & & $65.21 \pm 0.018^{*}$ & $104.70 \pm 0.071$ & $45.03 \pm 0.019^{*}$ & $97.37 \pm 0.026$ & $3.60 \pm 0.019$ & $91.13 \pm 0.022$ \\
\hline K. fumarate & $53.77 \pm 0.007^{*}$ & $87.48 \pm 0.007$ & $58.92 \pm 0.002^{*}$ & $87.67 \pm 0.008$ & $108.22 \pm 0.004^{*}$ & $89.51 \pm 0.003$ & & & & \\
\hline \multicolumn{11}{|l|}{$1.0 \%$ Pepsin } \\
\hline $0 \mathrm{~min}$ & & & & & - & $79.27 \pm 0.058$ & - & $99.96 \pm 0.005$ & - & $79.32 \pm 0.022$ \\
\hline $30 \mathrm{~min}$ & & & & & - & $99.47 \pm 0.086$ & - & $85.50 \pm 0.005$ & - & $79.39 \pm 0.011$ \\
\hline $1 \mathrm{~h}$ & & & & & - & $94.60 \pm 0.068$ & - & $84.35 \pm 0.005$ & - & $88.45 \pm 0.021$ \\
\hline $2 \mathrm{~h}$ & & & & & $54.39 \pm 0.019^{*}$ & $95.64 \pm 0.073$ & - & $88.45 \pm 0.001$ & - & $86.93 \pm 0.014$ \\
\hline $4 \mathrm{~h}$ & & & & & - & $99.28 \pm 0.076$ & - & $83.31 \pm 0.009$ & - & $88.02 \pm 0.017$ \\
\hline $8 \mathrm{~h}$ & & & & & - & $95.12 \pm 0.092$ & $20.8 \pm 0.026^{*}$ & $81.53 \pm 0.005$ & - & $84.72 \pm 0.012$ \\
\hline \multicolumn{11}{|l|}{$1.5 \%$ Pepsin } \\
\hline $0 \mathrm{~min}$ & & & & & - & $103.29 \pm 0.071$ & - & $83.12 \pm 0.074$ & - & $99.52 \pm 0.014$ \\
\hline $30 \mathrm{~min}$ & & & & & - & $94.08 \pm 0.069$ & - & $98.98 \pm 0.017$ & - & $98.73 \pm 0.014$ \\
\hline $1 \mathrm{~h}$ & & & & & - & $97.59 \pm 0.069$ & $72.47 \pm 0.007^{*}$ & $94.05 \pm 0.025$ & $2.12 \pm 0.021$ & $100.14 \pm 0.028$ \\
\hline $2 \mathrm{~h}$ & & & & & - & $108.25 \pm 0.067$ & $60.23 \pm 0.010^{*}$ & $87.72 \pm 0.038$ & - & $93.05 \pm 0.012$ \\
\hline $4 \mathrm{~h}$ & & & & & - & $102.33 \pm 0.067$ & - & $88.22 \pm 0.007$ & - & $88.16 \pm 0.016$ \\
\hline $8 \mathrm{~h}$ & & & & & - & $83.70 \pm 0.052$ & $28.36 \pm 0.024^{*}$ & $76.71 \pm 0.023$ & - & $86.77 \pm 0.004$ \\
\hline
\end{tabular}




\section{Amino acid composition of SPHs prepared with pepsin}

Gleanings from aforementioned experiments led to the analysis of the amino acid compositions of SPH prepared with pepsin, which was then compared to SPI (shown in Table 5). The quantitative differences in amino acid compositions between them can be attributed to the hydrolytic process involved in the preparation of SPH that might have contributed to the disparity. Certain chemical reactions, including protein denaturation and mallard reaction, may lead to loss of amino acids. Additionally, an increase in applied energy and decrease in water (such as freeze-drying) caused a significant reduction of arginine (38.32\%) in this experiment. Whereas percentage losses of lysine, arginine, histidine, cysteine, methionine and tryptophan in an extrusion process had been previously reported to be $30-40 \%, 7-21 \%, 15 \%, 8-21 \%, 14 \%$, and $14 \%$ respectively [40], and established lysine to be the most sensitive amino acid to damage during processing and storage [41]. However, there is an increase in Ala, Asp, Glu, Gly, His, Hyp, Ile, Leu, Lys, Met, Phe, Pro, Ser, Thr, Trp, Tyr, Val, and Gln compositions, with the essential amino acids (EAAs) being entirely intact in the hydrolysed soy protein prepared with pepsin. It has been reported that plant proteins do not contain high amounts of EAAs compared to animal proteins [42], thereby making the result obtained in this experiment conceivable. Finally, this study relates harmoniously with the report of Fleddermann et al [43] who studied some cereal proteins, including SPI and reported the similarity of their bioavailability in human nutrition based on the requirement of FAO/WHO/UNO for preschool children (1-2 y) [44], and further maintained that soy protein exhibited true digestibility, especially when hydrolysed into smaller peptides.

Table 5. Comparison of AAs from pepsin-educed SPH with SPI

\begin{tabular}{|c|c|c|c|c|}
\hline$\frac{\text { Amino acid }}{\text { composition }}$ & SPI (\%) & SPH (\%) & $\frac{\text { Essential }}{\text { Amino Acids }}$ & $\underline{\text { Non-Essential Amino Acids }}$ \\
\hline$\overline{\text { Alanine }}$ & 3.02 & 5.54 & $\overline{\text { Histidine }}$ & Alanine \\
\hline Arginine & 48.08 & 9.76 & Isoleucine & Arginine* \\
\hline Aspartic acid & 4.51 & 6.56 & Leucine & Aspartic acid \\
\hline Cystine & 0.59 & 0.31 & Lysine & Cystine* \\
\hline Glutamic acid & 3.64 & 7.22 & Methionine & Cysteine* \\
\hline Glycine & 2.38 & 4.56 & Phenylalanine & Glutamic acid \\
\hline Histidine & 1.42 & 2.15 & Threonine & Glutamine* \\
\hline Hydroxylysine & 0.00 & 0.00 & Tryptophan & Glycine* \\
\hline Hydroxyproline & 0.05 & 0.15 & Valine & Proline* \\
\hline Isoleucine & 4.15 & 6.32 & & Serine* \\
\hline Leucine & 4.24 & 8.88 & & Tyrosine* \\
\hline Lysine & 3.90 & 8.65 & & Asparagine* \\
\hline Methionine & 2.43 & 2.99 & & Hydroxylysine \\
\hline Phenylalanine & 3.24 & 4.95 & & Hydroxyproline \\
\hline Proline & 3.72 & 7.41 & & \\
\hline Serine & 3.25 & 5.70 & & \\
\hline Threonine & 2.95 & 3.76 & & \\
\hline Tryptophan & 0.74 & 0.80 & & \\
\hline Tyrosine & 2.31 & 2.74 & & \\
\hline Valine & 2.30 & 3.55 & & \\
\hline Asparagine & 0.00 & 0.00 & & \\
\hline Cysteine & 0.18 & 0.00 & & \\
\hline Glutamine & 2.89 & 8.00 & & \\
\hline TOTAL & 100 & 100 & & \\
\hline
\end{tabular}

SPI = soy protein isolate; $\mathrm{SPH}=$ soy protein hydrolysate;

*conditionally essential (not usually required in the human diet, but do become essential under certain circumstances such as illness and stress) 


\section{CONCLUSION}

Observations on the effects of SPHs on RBL-2H3 cell degranulation prompted our hypothesis that soy protein isolate hydrolysed with alcalase, having the conditions of $0.5 \%$ $\mathrm{E} / \mathrm{S}$ and hydrolysis time of $4 \mathrm{~h}$ at $0.1 \mathrm{mg} / \mathrm{mL}$ concentration, may reduce allergic symptoms. In the same vein, if hydrolysed with pepsin and subjected to the conditions of $0.5 \% \mathrm{E} / \mathrm{S}$ and hydrolysis time of $4 \mathrm{~h}$ and at $0.1 \mathrm{mg} / \mathrm{mL}$ concentration, similar results can be attained. Furthermore, the most potent SPH sample obtained in this study yielded essential amino acids (EAAs) suitable for quality human nutrition. Additionally, these results indicated that soy protein hydrolysates could be used as potential sources of low cost hypo or anti-allergic protein (with $86.66 \%$ and $87.70 \%$ protein recovery, and $\beta$-hexosaminidase release inhibition rate of $72.51 \%$ and $39.22 \%$ for pepsin and alcalase respectively) to produce functional immunomodulatory food products.

List of Abbreviations: SPI, Soy Protein Isolate; SPH, Soy Protein Hydrolysate; RBL, Rat Basophilic Leukemia; PNAG, $P$-nitrophenyl N-acetyl- $\beta$-D-glucosaminide; FBS, Fetal Bovine Serum; DNP, Dinitrophenol, PBS, Phosphate-buffered saline.

Authors' Contributions: Tolulope Joshua Ashaolu, $\mathrm{PhD}$, researcher is the main investigator for this study, contributed fundamental conceptualization for the research, wrote the manuscript as well as performed all the experiments. Chutha Takahashi Yupanqui, $\mathrm{PhD}$, is an expert on cell culture technique and the supervisor for the study. She provided oversight as well as revision of the written manuscript.

Competing Interests: The authors hereby declare no competing interests.

Acknowledgements and Funding: This work was supported by the Higher Education Research Promotion and the Thailand's Education Hub for Southern Region of ASEAN Countries Project Office of the Higher Education Commission. The authors are also grateful to Graduate school and Prince of Songkla University (Grant Number GRA 600428S) for their financial support.

\section{REFERENCES}

1. American Academy of Allergy: Asthma and Immunology (AAAAI). [Allergy statistics.http://www.aaaai.org/about-aaaai/newsroom/allergy-statistics]

2. Stone KD, Prussin C, Metcalfe DD: IgE, mast cells, basophils, and eosinophils. J Allergy \& Clin. Immunol 2010, 125: 73 - 80.

3. Guo YC, Li ZX, Lin H: Investigation on the relationship among histamine, tryptase and beta-hexosaminidase in the process of mast cell degranulation. J. Cell \& Mol Immunol 2009, 25 (12): 1073 - 1075. 
4. Tavano OL: Protein hydrolysis using proteases: an important tool for food biotechnology. J Mol Cat B: Enzy 2013, 90: 1 - 11.

5. Sicherer, SH: Food allergy. Lanc 2002, 360: $701-710$.

6. Hsu K: C. Purification of antioxidative peptides prepared from enzymatic hydrolysates of tuna dark muscle by-product. Food Chem 2010, 122: 42 - 48.

7. Food Allergy Research Education (FARE): Soy allergy. [https://www.foodallergy.org/allergens/soy-allergy]

8. Sicherer SH, Sampson HA: Food allergy. J Allergy Clin Immunol 2006, 117: 470 475 .

9. Holzhauser T, Wackermann O, Ballmer-Weber BK, Bindslev-Jensen C, Scibilia J, Perono-Garoffo L et al.: Soybean (Glycine max) allergy in Europe: Gly m 5 (betaconglycinin) and Gly m 6 (glycinin) are potential diagnostic markers for severe allergic reactions to soy. J Allergy \& Clin Immunol 2009, 123 (2): 452 - 458.

10. Amnuaycheewa P, de Mejia EG: Purification, characterisation, and quantification of the soy allergen profile in (Gly m 3) in soy products. Food Chem 2010, 119 (4): 1671 -1680 .

11. Walter J, Greenberg Y, Sriramarao P, Ismail BP: Limited hydrolysis combined with controlled Maillard-induced glycation does not reduce immunoreactivity of soy protein for all sera tested. Food Chem 2016, 213: 742 - 752.

12. Jung S, Roussel-Philippe C, Briggs JL, Murphy PA, Johnson L: Limited hydrolysis of soy proteins with endo- and exoproteases. J Amer Oil Chem Soc 2004, 81: 953 96.

13. Hrckova' M, Rusn a' kova' M, Zemanovic J: Enzymatic hydrolysis of defatted soy flour by three different proteases and their effect on the functional properties of resulting protein hydrolysates. Czech J Food Sci 2002, 20: 7 - 14.

14. Peñas E, Pre'stamo G, Polo F, Gomez R: Enzymatic proteolysis, under high pressure of soybean whey: analysis of peptides and the allergen Gly $\mathrm{m} 1$ in the hydrolysates. Food Chem 2006, 99: 569 - 73.

15. Xiang ZK, Ming MG, Yu FH, Dong C, Cai MZ: Enzymatic preparation of immunomodulating hydrolysates from soy proteins. Biores Technol 2008, 99: 8873 -8879 .

16. Meinlschmidt P, Schweiggert-Weisz U, Brode V, Eisner P: Enzyme assisted degradation of potential soy protein allergens with special emphasis on the technofunctionality and the avoidance of a bitter taste formation, LWT - Food Sci. \& Technol 2016, 68: 707 - 716.

17. Ezequiel RC, Maria MA, Glenise BV, Bibiana BN, Guillermo AP, Manuela EP: Bioactive properties of peptides obtained from Argentinian defatted soy flour protein by Corolase PP hydrolysis. Food Chem 2016, 198: 36 - 44. 
18. Adler-Nissen J, Olsen HS: The influence of peptide chain length on taste and functional properties of enzymatically modified soy protein. In Functionality and Protein Structure. Edited by Pour-El A, ACS Symposium Series. Washington DC; 1979: 125 - 146.

19. Ziegler F, Nitenberg G, Coudray-Lucas C, Lasser P, Giboudeau J, Cynober L: Pharmacokinetic assessment of an oligopeptide-based enteral formula in abdominal surgery patients. Amer J Clin Nutr 1998, 67: $124-128$.

20. Yoshikawa FM, Takahashi L: Immunomodulating peptide derived from soybean protein. Ann. NY Acad Sci 1993, 685: 375 - 376.

21. Moure A, Domínguez H, Parajó JC: Antioxidant properties of ultrafiltrationrecovered soy protein fractions from industrial effluents and their hydrolysates. Process Biochem 2006; 41: 447 - 456.

22. Chiang WD, Tsou MJ, Tsai ZY, Tsai TC: Angiotensin I-converting enzyme inhibitor derived from soy protein hydrolysate and produced by using membrane reactor. Food Chem 2006, 98: $725-732$.

23. Ringseis R, Matthes B, Lehmann V, Becker K, Schöps R, Ulbrich-Hofmann der K, $\mathrm{R}$ : Peptides and hydrolysates from casein and soy protein modulate the release of vasoactive substances from human aortic endothelial cells. Biochem Biophys Acta 2005, 1721: $89-97$.

24. Gibbs BF, Zougman A, Masse R, Mulligan C: Production and characterization of bioactive peptides from soy hydrolysate and soy fermented food. Food Res Int 2004, 37: $123-31$.

25. Boyce COL, Lanzilotta RP, Wong TM: Enzyme modified soy protein for use as an egg white substitute. US Pat No. 4, 632, 903; 1986.

26. Amerongen AV, Thomissen MJCB, Zeeland WLAMV, Gilst WHV, Jan HB, Joseph WPMN: Egg protein hydrolysates. World Intellectual Property Organization, Patent no WO 2009128713 A1; 2009.

27. Nielsen PM, Petersen D, Dambmann C: Improved method for determining food protein degree of hydrolysis. Food Sci 2001, 66: 642 - 646.

28. AOAC International: Official methods of analysis of AOAC International $\left(6^{\text {th }} \mathrm{Ed}\right)$. Assoc. Official Anal Chem Washington DC 2005.

29. Mastuda H, Morikawa T, Ueda K, Managi H, Yoshikawa M: Structural requirements of flavonoids for inhibition of antigen-induced degranulation, TNF- $\alpha$ and IL-4 production from RBL-2H3 cells. Bioorganic \& med. Chem 2002, 10 (10), 3123 3128.

30. Adler-Nissen J: Controlled hydrolysis and the empirical characterization of various substrates and enzymes. In Enzymic hydrolysis of food protein. Edited by AdlerNissen J. New York: Elsevier Science Publishing Co; 1986: 145 - 60. 
31. Yust MM, Pedroche J, Giron-Calle J, Alaiz M, Millan F, Vioque MJ: Production of ACE inhibitory peptides by digestion of chickpea legumin with alcalase. Food Chem 2003, 81: $363-369$.

32. Guo ML, Jiang YM, Ma ZL, Li YL: Hydrolytic characteristics of chitosanimmobilized as 1.398 neutral proteinase (from B. subtilis) to soybean protein. Food Chem 1996, 55: 373 - 377.

33. Zhang XY, Xu P, Zhang HM: Suppressive Effects of Racanisodamine Hydrochloride on Degranulation and IL-4 Generation in IgE-Antigen Complex-Stimulated RBL2H3 Cells. Int J Intgr Med 2013, 1: 32.

34. Matsuda H, Sugimoto S, Morikawa $\mathrm{T}$ et al.: Bioactive constituent from chinese natural medicines: Inhibitors of antigen-induced degranulation in RBL-2H3 Cells from the seeds of Psoralea corylifolia. Chem Pharm Bull 2007, 55 (1): 106 - 110.

35. Matsuda H, Morikawa T, Ando S, Toguchida I, Yoshikaw M: Structural requirements of flavonoids for nitric oxide production inhibitory activity and mechanism of action. Bioorganic \& med Chem 2003, 11 (9): 1995 - 2000.

36. Sae-Wong C, Matsuda H, Tewtrakul S, Tansakul P, Nakamura S, Nomura Y, Yoshikawa M: Suppressive effects of methoxyflavonoids isolated from Kaempferia parviflora on inducible nitric oxide synthase (iNOS) expression in RAW 264.7 cells. J ethnopharm 2011, 136 (3): 488 - 495.

37. Udenigwe CC, Aluko RE: Food protein-derived bioactive peptides: production, processing and potential health benefits. J Food Sci 2012, 77: R11 - 24.

38. Chen JR, Yang SC, Suetsuna K, Chao JCJ: Soybean protein-derived hydrolysate affects blood pressure in spontaneously hypertensive rats. J Food Biochem 2004, 28: $61-73$.

39. Arnoldi A, D’Agostina A, Boschin G, Lovati MR, Manzoni C, Sirtori CR: Soy protein components active in the regulation of cholesterol homeostasis. In Biologically Active Phytochemicals in Food, RSC (Special Publication) 2001, 269: $103-106$.

40. Arêas JAG, Rocha-Oliveri CM, Marques MR: Extrusion cooking: chemical and nutritional changes, Encyl. food \& health 2016, 569 - 575.

41. Hurrell RF, Paul-André F: Food processing and storage as a determinant of protein and amino acid availability, In Nutritional Adequacy, Nutrient Availability and Needs. Birkhäuser Basel 1983, 135 - 156.

42. Kniskern MA, Johnston CS: Protein dietary reference intakes may be inadequate for vegetarians if low amounts of animal protein are consumed. Nutr 2011, 27: 727 730.

43. Fleddermann M, Anita F, Andrea R, Melanie B, Anja P, Frank L, Gerhard J: Nutritional evaluation of rapeseed protein compared to soy protein for quality, 
plasma amino acids, and nitrogen balance-a randomized cross-over intervention study in humans. Clin Nutr 2013, 32 (4): 519 - 526.

44. FAO/WHO/UNO: Protein and amino acid requirements in human nutrition, Technical Report Series, Geneva; 2007: 935. 